Library Acquisitions: Practice \& Theory, 1993, Vol. 17, Issue 4, p.413-416.

ISSN: 0364-6408

http://www.sciencedirect.com/

http://www.sciencedirect.com/science/journal/03646408/17

http://www.sciencedirect.com/science/article/pii/036464089390004P

http://dx.doi.org/10.1016/0364-6408(93)90004-P

(C) 1993 Pergamon Press Ltd.

\title{
AN INTERVIEW WITH GORDON GRAHAM, EDITOR OF LOGOS
}

\section{Interviewed by Carol Pitts Hawks, Editor-in-Chief}

\author{
GORDON GRAHAM
}

\begin{abstract}
This interview was conducted via mail in early 1993. Gordon Graham responds to a series of questions about the journal he founded and currently edits, LOGOS: The Professional Journal for the Book World.
\end{abstract}

\section{INTRODUCTORY NOTE}

In a 1990 issue of Dialogue published by Yankee Book Peddlar, Gordon Graham was referred to as "the most respected elder statesman of publishing and bookselling." [1] I first met Mr. Graham at the 1990 Charleston Conference where he spoke on the topic "Publishers, Librarians, and the Eternal Triangle" (LAPT V. 15, no. 3, pp. 261-264). Our conversation at that time focused on his career in the publishing world, how he had been drawn into the library world, and his interest in electronic publishing and international publishing. Since his retirement as CEO of Butterworths in 1990, Mr. Graham has focused his attention on the founding and editing of a new journal, LOGOS: The Professional Journal for the Book World. This interview focused on this new endeavor.

LAPT: Your newest endeavor since your retirement as CEO of Butterworths is a new journal, LOGOS: The Professional Journal for the Book World. Why this? Why now? How do you feel about its success two years into the project?

Graham: $L O G O S$ is not a new idea. It first came to me in 1974. I guess it touched me on the shoulder because in my publishing career I worked in three continents and travelled widely. This gave me an international sense. Also, I consorted enthusiastically with librarians and booksellers and have long felt that the book world is too compartmented, by both national and disciplinary boundaries. The idea has been implemented in the last two or three years because I became free to turn my attention to it. As to its success, when I was in Butterworths, which had a hundred journals, I used to say in public quite often that it took five to seven years for a journal to break even. $L O G O S$ is not proving an exception. On the other hand, by its nature, it does not seek large numbers. The number of subscriptions is limited partly by the present climate, when more subscriptions are being cancelled than initiated, and partly by the fact that people subscribe most 
readily to journals which cater to their specific interests. However, I am satisfied that the influence of $L O G O S$ is greater than its numbers, because of the high quality of the contributors and readers. While the subscriptions are counted in hundreds, the readers run to thousands, through offprints and photocopies.

LAPT: You have described your advisory board as "... a unique cadre of people of diverse backgrounds, but common interests, who have not previously been linked together." [2] Can you tell me more about them and what role they play with the journal? You have some unique requirements for your editorial board members. Could you share those policies and your thoughts in setting them with our readers?

Graham: The Advisory Board almost picked itself. I simply approached publishers, librarians, booksellers etc. who are prominent, concerned, and thoughtful, in the principal publishing countries. Their contribution to the journal has been significant, but uneven. They are all on a three-year term, and I am now in the process of replacing some, and asking others to renew their terms.

LAPT: I am fascinated by what you see as your guiding philosophy of LOGOS. You have stated that "LOGOS articles will ... be based on experience and written out of a sense of conviction. While I will receive and welcome material in finished or synoptic form, my duty is to identify topics and write to prospective contributors whose reputation and records suggest they have something to say." [3] How do you identify these contributors?

Graham: The contributors also pick themselves. They are simply the top people, or likely to become top people, in their particular fields. The problem is not to find them, but to persuade them to write. Although all are in the word business, few of them are professional writers. I have found that the typical LOGOS article falls into four parts - some history, some personal experience, critical analysis of the subject, and a view of the future. We are able to offer strong editorial collaboration and plenty of scope, since we are flexible as to length. I very seldom have to cut pieces, although I streamline them. I quite often have to draw more material out of contributors.

LAPT: I am intrigued by the LOGOS Royalty Trust Fund, which you established in conjunction with the journal. Can you explain how that works? Do you believe that it could be a model for other publications?

Graham: The LOGOS Royalty Trust Fund is still a gleam in my eye, because the journal has not yet broken even. When it does break even, I plan to devote half of my editorial royalties, plus any other contributions I can muster, to causes which are in line with the LOGOS theme. For example, one thing I would like to do as soon as I can is place subscriptions in the hands of key librarians, publishers, and booksellers in developing countries that are short of funds and foreign exchange. I doubt if it could be a model for other publications, unless they belong to not-for-profit bodies. The idea does incidentally illustrate the difference which I see between a professional and a scholarly journal. In a professional journal we are asking people to share their experience with their colleagues. They do not write to embody research, or to build their reputations. Most of them already have reputations! Nor do I ask them to engage in research. They simply write about what they know. 
LAPT: To what extent do you think your diverse background helps you with LOGOS'!

Graham: I suppose $L O G O S$ is the product of my diverse background (see the first question/answer). On the other hand, if the idea is good, it has to have a life of its own, and continue after I have gone. The enthusiasm of many of the contributors and readers leads me to believe that this will happen.

LAPT: What is coming along next in LOGOS!

Graham: If you look through the first ten issues of $L O G O S$, you will be able to trace the development of new ideas. For example, we try to engender "debates in print," where opposing views are juxtaposed. We also try to retain a balance in each issue between the developed and the developing worlds, which have too little contact. In a forthcoming issue, we are publishing my correspondence with a Chinese official about freedom to publish, followed by the article which he wrote in consequence. The topics for articles are almost endless. The editorial task is to settle their priorities and to find potential contributors and persuade them to write. I have a fairly high failure rate, which does not worry me. Sometimes people surface months or years after I have written to them. I hope to have more articles from Africa, Asia, and Latin America than I have so far achieved - not from lack of trying. I would also like to have more female contributors. I think the small number so far tends to reflect the gender imbalance of the book industry.

$L A P T$ : What do you see as the obstacles and opportunities for $L O G O S^{\prime}$ future success?

Graham: The main opportunity for $L O G O S$ is to establish itself as a permanent reference work. Most of the articles are timeless, and we have started, with the first issue of the third volume, to publish a cumulative index. We do not wish it to be seen as a periodical which is read and discarded. The main obstacle is that members of the world book community tend to be concerned mainly with their individual interests and responsibilities. If $L O G O S$ can get them to see that they are part of a larger fabric, $L O G O S$ will succeed correspondingly. This will be a slow process.

LAPT: Can you provide our readers with basic information on your subscriber base?

Graham: We have just over 400 subscribers, about $60 \%$ of whom are institutions. We have a good renewal rate, but better for institutions than individuals. The U.S. and the U.K. provide about two-thirds of the subscriptions, the balance being scattered all over the world.

LAPT: Are there things you would like to do eventually that time and circumstances don't permit at this point?

Graham: I don't feel limited by present circumstances. $L O G O S$ is principally concerned with the articulation and spread of ideas. It does not seek to become a large institution. Its job is constructive leavening.

LAPT: You've been interviewed a number of times over the years and asked a lot of questions to end interviews. What would you like the last question of your interview to be? 
Graham: I suppose, being more commercially minded than I sound, my favorite concluding question would be: What can I do to help? I enclose a leaflet, in the hope that there might be some means of getting it into the hands of your readers.

Editor's Note: A review of $L O G O S$ by Thomas Nisonger appears in the Review Section of this issue. Subscription information and the publisher's address can be found in that review.

\section{REFERENCES}

1. Dialogue: The Business of Publishing (October 1990), 4.

2. Graham, Gordon. "The Evolution of a Journal: a Personal Perspective," Ulrich's News, 3 (June/July 1990), 4.

3. Ibid. 